\title{
censoring を受けた年最大值資料に対する極値 統計解析結果の相互比較 INTERCOMPARISON OF EXTREME VALUE ANALYSES FOR CENSORED ANNUAL MAXIMUM SAMPLE
}

\author{
宇都宮好博 1 ・ 山口正隆 2 ・野中浩一 3 ・畑田佳男 4 \\ Yoshihiro UTSUNOMIYA, Masataka YAMAGUCHI, Hirokazu NONAKA and Yoshio HATADA \\ 1 正会員 工修 (財)日本気象協会首都圏支社 (广170-6055 東京都豊島区東池袋 3 丁目 1 番 1 号) \\ 2 正会員 工博 愛媛大学教授 工学部環境建設工学科 (下 790-8577 松山市文京町 3) \\ 3 正会員 博(工学) 愛媛大学契約職員 工学部環境建設工学科 (T 790-8577 松山市文京町 3) \\ 4 正会員 博(工学) 愛媛大学講師 工学部環境建設工学科 († 790-8577 松山市文京町 3)
}

\begin{abstract}
Accuracy of parameter estimation methods to be used in extreme value analyses for censored annual maximum samples is investigated using a Monte-Carlo simulation technique. The methods are maximum likelihood method(MLM), least square method(LSM) and partial probability weighted moment(PPWM) method, and probability distributions are Gumbel, shape parameter-fixed GEV and Weibull distributions. MLM yields more efficient estimates of quantiles than PPWM method and LSM even for censored samples. MLM-, LSM- and PPWM-based models are applied to extreme value analyses to several types of censored in-situ annual maximum samples. One finding is that inclusion of historical information in MLM- and PPWM-based models produces more efficient estimates of quantiles.
\end{abstract}

Key Words : censored sample, annual maximum data, MLM, LSM, PPWM, historical information

\section{1. 緒 言}

欠落を伴う年最大値資料や異常值に限定された歴史情 報を含む年最大值資料に対する極值統計解析において， これらの資料をcensoringを受けた標本資料 (censored sample) とみなしたうえで, 候補確率分布の母数推定を 最尤法 ${ }^{1)}$ (Maximum Likelihood Method；MLM)，最小2 乗法) (Least Square Method；LSM），部分確率加重積率 (Partial Probability Weighted Moment ; PPWM) 法3)などに より行うモデルか提案されている．しかし，弚れ光れの 方法の適用性を広範囲に相互比較した研究事例はあまり 見当たらない．

そこで本研究では, Gumbel分布, 形状母数固定型GEV 分布, 形状母数固定型Weibull分布の2母数分布を対象と して, 各種censoring条件のもとでの広範なモンテカルロ シミュレーション結果の検討から, 各母数推定法の再現 確率統計量に対する推定精度や分散に対するjackknife法 ${ }^{1,3,3}$ などの推定精度を調査するとともに，これらの 2 母数 分布て構成した極值統計解析モデルを, censoringを受け た現地資料の解析に適用し, 再現確率統計量と光の分散 の推定値の相互比較を行う .

\section{2. 候補確率分布と母数および分散の推定法}

\section{（1）候補確率分布}

Gumbel 分布, GEV 分布およびWeibull 分布は $H$ を確 率変量, $F(H)$ を確率分布関数, $A$ を尺度母数, $B$ を位 置母数, $k$ を形状母数として, 乥れ光れ次式て表される.

$$
\begin{gathered}
F(H)=\exp [-\exp \{-(H-B) / A\}],-\infty<H<\infty \\
F(H)=\exp \left[-\{1-k(H-B) / A\}^{1 / k}\right], \\
k<0: B+A / k<H<\infty \\
k>0:-\infty<H<B+A / k \\
F(H)=1-\exp \left[-\{(H-B) / A\}^{k}\right], B<H<\infty
\end{gathered}
$$

\section{( 2) 母数推定法}

a) 最尤法

censoring とは標本の中で, ある值より大きいあるいは 小さい資料を除去する操作 ${ }^{2)}$ を言う . censoring は年の基 準值か涸定され, censoring を受ける資料の個数がランダ ムである第 1 種 censoring と, 基準值がランダムで資料の 
個数力涸定される第 2 種 censoring $の 2$ 種類に ,また基準 值によって上限, 下限, 上下限 censoring の 3 種類の, 合 計 6 種類 ${ }^{11}$ に分類される .

資料期間 $K$ 年で大きさ $N$ 個 $(K=N) \sigma$ 年最大值標本 資料 $H_{i}$ のうち, 下限値 $H_{L}$ より小さい $p$ 個と上限値 $H_{U}$ より大きい $q$ 個が censoring を受けている場合に，第 1 種 censoring 問題(下限値 $H_{L}$, 上限值 $H_{U}$ は固定, $p, q$ は ランダム)に対する尤度関数 $L_{1}{ }^{1}{ }^{1}$ は次式で表される。

$$
L_{1} \propto F\left(H_{L}\right)^{p} \bullet \prod_{i=1}^{n} f\left(H_{i}\right) \bullet\left\{\left(1-F\left(H_{U}\right)\right\}^{q}\right.
$$

ここに, $f\left(H_{i}\right)$ は確率密度関数, $n=N-p-q$, であ る.一方, 第 2 種 censoring 問題 $\left(p, q\right.$ は固定, $H_{p+1}$, $H_{N-q}$ (ラランダム) に対する尤度関数 $\left.L_{2}{ }^{1}\right)$ は次式になる。

$$
L_{2} \propto\left\{F\left(H_{p+1}\right)\right\}^{p} \bullet \prod_{i=p+1}^{N-q} f\left(H_{i}\right) \bullet\left\{1-F\left(H_{N-q}\right)\right\}^{q}
$$

また，資料期間 $K$ を歴史資料の期間 $K_{1}$ ，新しい時代 の観測資料の期間 $K_{2}$ ，古い時代の観測資料(観測值が異 常年のみ記録されている)の期間 $K_{3}$ より成ると考えて， 期間 $K_{1}$ では閾值 $H_{U 1}$ 以上の出現回数 $q_{1}$ のみ既知, 期間 $K_{2}$ では $H_{L 2}$ より小さい資料 $p_{2}$ 個の值と $H_{U 2}$ より大き い資料 $q_{2}$ 個の值力不明, 期間 $K_{3}$ では $H_{L 3}$ より小さい資 料 $p_{3}$ 個の值と $H_{U 3}$ より大きい資料 $q_{3}$ 個の值か不明とす れば, この場合の尤度関数 $L$ はつぎのように表される．

$$
\begin{gathered}
L \propto\left[F\left(H_{U 1}\right)^{K_{1}-q_{1}}\left\{1-F\left(H_{U 1}\right)\right\}^{q_{1}}\right] \bullet \\
{\left[F\left(H_{L 2}\right)^{p_{2}} \bullet \prod_{i=1}^{n_{2}} f\left(H_{i}\right) \bullet\left\{1-F\left(H_{U 2}\right)\right\}^{q_{2}}\right] \bullet} \\
{\left[F\left(H_{L 3}\right)^{p_{3}} \bullet \prod_{i=1}^{n_{3}} f\left(H_{i}\right) \bullet\left\{1-F\left(H_{U 3}\right)\right\}^{q_{3}}\right]}
\end{gathered}
$$

ここに $, n_{2}=K_{2}-p_{2}-q_{2}, n_{3}=K_{3}-p_{3}-q_{3}$ である.式 (4)および式(5)はシミュレーション資料の解析に，式(6) は歴史資料を含む現地資料の解析に用いる.最尤解は，

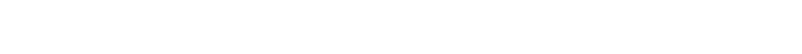
得られる.このとき, 最大対数尤度 MLL は標本に対す る候補確率分布の適合度を表す指標になる。

b) 最小2乗法

モンテカルロシミュレーション結果を用いて , 再現確 率統計量のbiasをできるだけ小さくするように候補確率 分布ごとに係数を決めたプロッティング位置公式 $)^{2} に よ$ って, 各資料值の非超過確率 $F_{i}$ およひ基準化変量 $y_{i}$ を求 めたのち, 順序統計量 $H_{i}$ と基準化変量 $y_{i}$ の関係が直線 で表されるとして, 尺度母数 $A$ と位置母数 $B$ を最小 2 乗 法により算出する .

c) PPWW法

PPWM は一般に次式で定義される .

$$
M_{p, r, s}=\int_{F_{1}}^{F_{2}} H(F)^{p} F^{r}(1-F)^{s} d F
$$

ここに， $F_{1} ， F_{2}$ はと珖れ censoring 条件の下限值と上 限值を与える非超過確率である.上式において，Gumbel 分布と GEV 分布の場合には $p=1, s=0$ とした $M_{1, r, 0}\left(=\beta_{r}\right)$, Weibull 分布の場合には $p=1, r=0$ とした $M_{1,0, s}\left(=\beta_{s}\right)$ を用いる.PPWM 法は，標本資料から得ら れる標本 PPWM と光れに相当する理論 PPWM を等値す ることにより，確率分布の母数を推定する方法である .2 母数分布の母数推定に対して,$r=(0,1)$ または $s=(0$, 1) とする低次 PPWM の場合を Irs $=0 ，(2,3)$ とする高 次 $\mathrm{PPWM}^{3}$ の場合をIrs =2 で表わす．

歴史資料を含む年最大值資料を取扱う場合には，観測 資料期間 $m$ 年と歴史資料期間 $K-m$ 年よりなる全資料 期間 $K$ 年において, $m$ 年間の観測資料のうち，下限 censoring 值以上でか $F_{2}$ に相当する基準値 $H_{c}$ より小 さい資料を上下限 censoring 問題として, また基準値 $H_{c}$ 以上の上位 $l$ 個の資料（観測期間における資料を含む可 能性あり)を下限 censoring 問題として処理して求めた艺

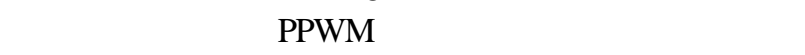
標本全体の PPWM を算定したのち, 候補確率分布の理 論 PPWM と等值して母数を算出する.

\section{（3）分散推定法}

再現確率統計量のbias補正や分散の推定のために， censored sampleに対してもjackknife法)を用いる.ただし， PPWM法や最小2乗法の場合， jackknife法によりbias補正 を行ってもbiasが必ずしも減少しないので, bias補正を最 尤法の場合 ${ }^{1)}$ に限定する . また最尤法による漸近的分散 推定法として，観測情報行列法卓を用いる。

\section{3. シミュレーション結果の検討}

(1) モンテカルロシミュレーションの概要

母分布か明らかな場合のモンテカルロシミュレーショ

ンを完全標本条件およひ第 1 種と第 2 種下限・上限・上 下限 censoring 条件のもとに資料年数 $K=10 \sim 100$ の 7 通 りについて 5,000 回(最尤法 最小2 乗法)あるいは 10,000 回 (PPWM 法) 実施し, 再現確率統計量の bias と分散平 方根 (標準偏差) $\mathrm{Var}^{1 / 2}$ に及ぼす censoring 条件などの影 響や, jackknife 法と観測青報行列法のVar ${ }^{1 / 2}$ に対する推 定精度を調べる .この場合, シミュレーション回数が多 いことから , 回数の差の影響は小さい .

誤差統計量は, 再現期間 100 年に対して, 確率統計量 の真值で無次元化した bias $\Delta \tilde{H}$ または jackknife 法によ る補正後のbias $\Delta \tilde{H}_{j}$ と確率統計量の分散平方根 $\tilde{V} a r^{1 / 2}$, 


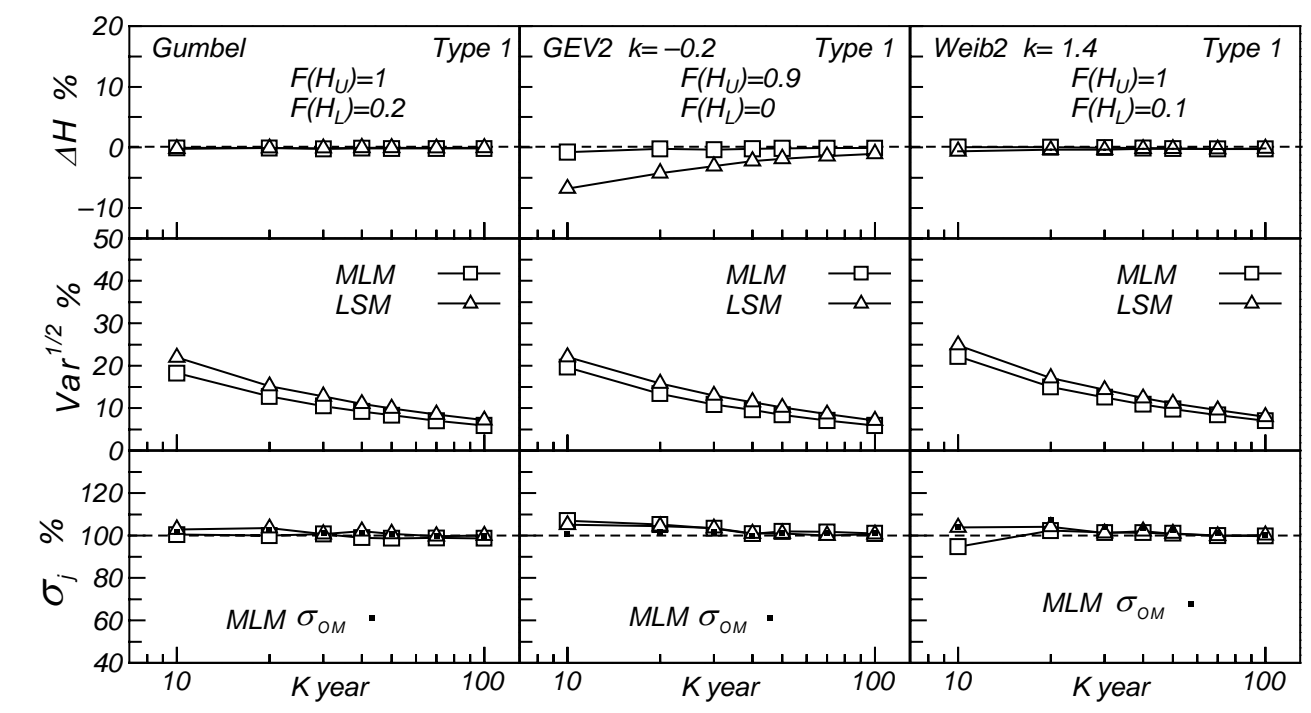

図-1 誤差統計量と資料年数の関係 (第 1 種 censoring)

およびVar ${ }^{1 / 2}$ て無次元化したjackknife法による分散推定 值の平均值と観測情報行列法による分散推定値の平方根 $\left(\tilde{\sigma}_{j} ， \tilde{\sigma}_{O M}\right)$ に対するパーセント值で表す.

\section{（2）シミュレーション結果の相互比較}

\section{a) 第1種 censor ed sampl e に対する比較}

図-1はGumbel分布 $(A=1.39, B=4.5)$, 形状母数固定型 GEV分布 $(k=-0.2, A=1.0, B=5.0)$ および形状母数 固定型Weibull分布 $(k=1.4, A=4.0, B=1.0)$ を产れ光 れ母分布とする第1種censored sampleに対するシミュレ ーション結果の誤差統計量と資料年数 $K$ の関係を例示 する. 各図は左から順に, Gumbel分布で下限censoring条 件 $\left(F\left(H_{U}\right)=1, F\left(H_{L}\right)=0.2\right)$, 形状母数固定型GEV分布

(GEV2) で上限censoring条件 $\left(F\left(H_{U}\right)=0.9, F\left(H_{L}\right)=0\right)$ および形状母数固定型Weibull分布 (Weib2) で下限 censoring条件 $\left(F\left(H_{U}\right)=1, F\left(H_{L}\right)=0.1\right)$ の場合を表す . 母数推定は最尤法(MLM) と最小2乗法(LSM)に依る.また， 最尤法に基づいて推定した再現確率統計量のbiasは jackknife法による補正後のbias $\Delta H_{j}$ である .

種々の検討から，つぎの特徽力指摘される .

(1)最尤法の場合，完全標本条件のみならずいずれの censoring 条件においても, 分布の種類や形状母数によら ずbias は非常に小さい . $\operatorname{Var}^{1 / 2}$ は，とくに完全標本条件 や下限 censoring 条件ではGEV2て形状母数の絶対值か大 きいほど，最小2 乗法を用いる場合よりかなり小さい． また , $\operatorname{Var}^{1 / 2}$ に対する jackknife 法の推定精度はかなり高 く 観測情報行列法の精度は，上限および上下限 censoring 条件でjackknife 法の光れを上まわる。

(2)最小 2 乗法の場合，bias は完全標本条件および下限 censoring 条件では分布の種類や形状母数によらず小さい が,上限および上下限 censoring 条件では資料年数，すな わち標本の大きさが小さいほど, また GEV2 て形状母数 の絶対值か大きく正側に分布の裾を長く引くほど，負の
值を増加させる . jackknife 法はVar ${ }^{1 / 2}$ の推定に対して censoring 条件によらずかなり高い精度を与える。

b) 第2種 censor ed sampl e に対する比較

図- 2 は図- 1 と同じ母分布条件のもとでの第 2 種 censored sample に対するシミュレーション結果の誤差統 計量と資料年数の関係を表す. 各図は Gumbel 分布で上 限 censoring 条件 $\left(\mu_{T}=0.1, \mu_{L}=0\right)$, 形状母数固定型 GEV 分布で下限 censoring 条件 $\left(\mu_{T}=0, \mu_{L}=0.1\right)$, 形状母数固 定型Weibull 分布で下限 censoring 条件 $\left(\mu_{T}=0, \mu_{L}=0.1\right)$ の場合に相当する $. \mu_{T}, \mu_{L}$ は乥れ光れ標本の上限，下 限 censoring 比を意味する. 母数推定法は最尤法(MLM) , 最小 2 乗法(LSM)，PPWM 法である.また , PPWM 法で 下限 censoring 条件の場合, 形状母数固定型 GEV 分布に 対して PPWM の次数を Irs $=0$ と I I $s=2$ の 2 通り示す. これ以外の場合には，Irs $=0$ のケースを採用する .

広範な検討から，つぎの特徽を指摘できる。

(1)最尤法の場合 , 分布の種類や censoring 条件によらず， 標本の大きさがさくなるほど最大 $5 \%$ の負の bias を生 じる . Var ${ }^{1 / 2}$ は他の方法の場合より小さい . $\operatorname{Var}^{1 / 2}$ に対 する jackknife 法およひ観測情報行列法の精度はいずれも 高い . とくに , 後者の精度力優れている．

(2)最小 2 乗法の場合，いずれの censoring 条件においても bias は3つの方法のうち最も小さい . $V a r^{1 / 2}$ は censoring 条件によらず, Gumbel 分布や形状母数固定型Weibull 分 布のケースでは, 最も小さい值を与える最尤法による值 と比べてやや大きい程度であるが, 形状母数固定型 GEV 分布のケースでは最尤法による值をかなり上まわる . ま た， $\mathrm{Var}^{1 / 2}$ に対する jackknife 法の精度は，下限 censoring 条件では分布によらず高いのに対して, 上限・上下限 censoring 条件では標本の大きさが小さいほど, 最大 $20 \%$ 程度過大な値を与える。

(3)PPWM 法の場合, Gumbel 分布や形状母数固定型 GEV 分布に対して, 高次 PPWM ケース $($ Irs =2) では bias は 


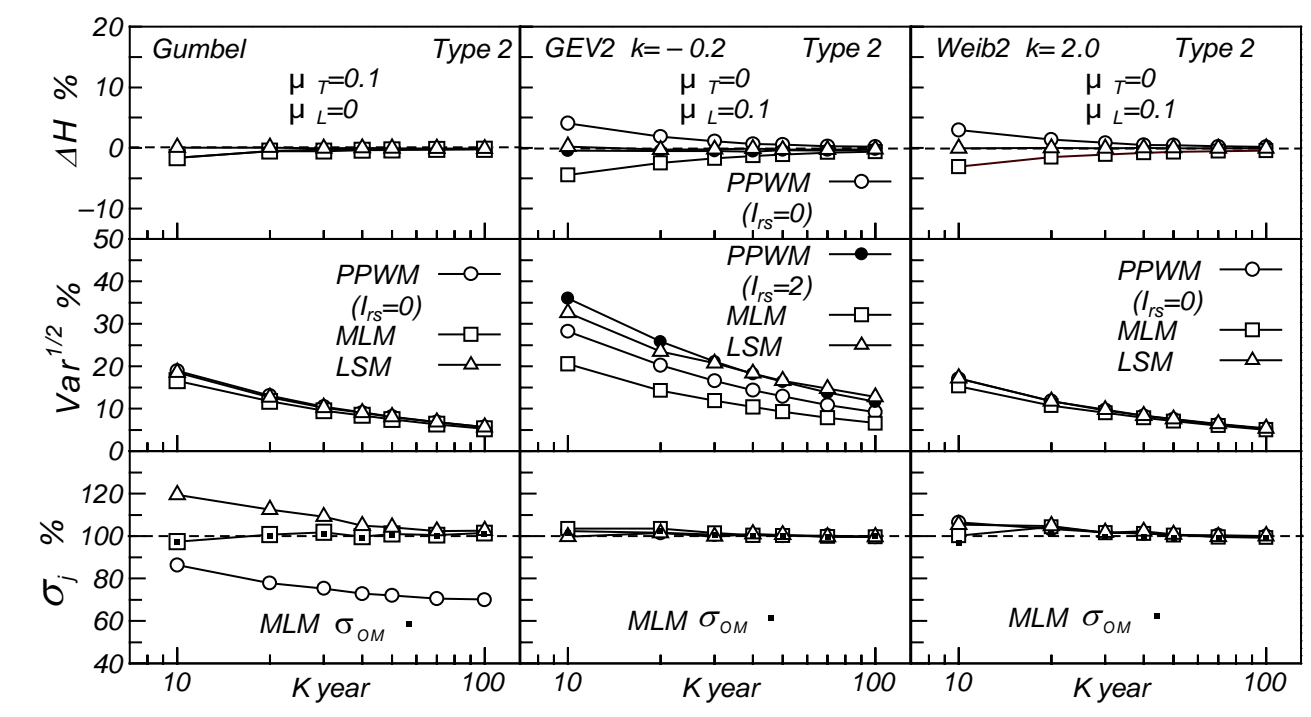

図-2 誤差統計量と資料年数の関係 (第 2 種 censoring)

小さいが, $\operatorname{Var}^{1 / 2}$ は最小 2 乗法によるものと同程度か， より大きい. 一方, 低次 PPWM ケース (Irs=0) では， bias は標本の大きさがささいど正の有意な値をとるが, $\operatorname{Var}^{1 / 2}$ は最小 2 乗法によるものより小さい . 形状母数固 定型Weibull 分布に対して, bias は下限 censoring 条件で 小さい正の值をとり, 上限 censoring 条件では 0 に近い . $\operatorname{Var}^{1 / 2}$ はいずれの censoring 条件でも最尤法による值よ りやや大きく，最小 2 乗法による值と同程度である． jackknife 法は $\operatorname{Var}^{1 / 2}$ に対して下限 censoring 条件で高い精 度を与えるが，上限 censoring 条件ではVar ${ }^{1 / 2} を 20 〜 30 \%$ 過小評価する。

\section{4 . 現地資料の解析}

\section{(1) 極值統計解析モデルの構成}

母分布が末知である現地資料に適用しうる極值統計解 析モデルにおける候補確率分布として, Gumbel 分布, 形 状母数固定型 GEV 分布, 形状母数固定型Weibull 分布の 2 母数分布を用いる. 形状母数固定型 GEV 分布の場合, 形状母数 $k$ は $-0.4 \sim 0.4$ の間で, $k^{\prime}=-1 / k$, ()内の数值 を刻み幅として ,PPWM 法と最尤法では $k^{\prime}=2.5 \sim 5(0.5)$, 6〜10 (1)，12.5〜25 (2.5)，30〜40 (5)，の正負両方の 值をとる 40 種類, 最小 2 乗法では $k^{\prime}$ に対して正の值を もつ 20 種類である. 一方, 形状母数固定型 Weibull 分布 の場合, 形状母数 $k$ は $0.5 \sim 10$ の間で $0.5 \sim 2.0(0.1), 2.2$ 〜3.0 (0.2) , 3.5〜5.0 (0.5) , 7, 10 の 27 種類である.以 上の值は形状母数による分布形状の変化に有意な差力生 じるように , 不等間融で与えている. 各母数推定法に基 ブくモデルはつぎのようである .

(1)最尤法モデル ${ }^{1)} て ゙$, 最適分布の選択を最大対数尤度

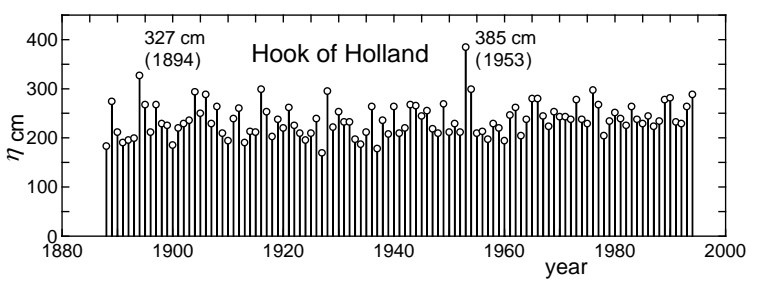

图-3 年最大海水位資料の時系列

基準 , 再現確率統計量の bias 補正を jackknife 法 , 再現確 率統計量の分散の推定を観測情報行列法による .

(2)最小 2 乗法モデルでは, 資料値のプロッティング位置 の算出を合田 ${ }^{2)}$ の式 , 最適分布の選択を最大相関係数基 準，再現確率統計量の分散の推定を jackknife 法による .

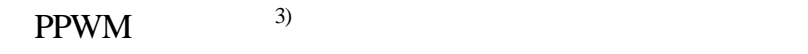
数基準, 相関係数の計算に必要な各資料値に対するプロ ッティング位置の算出を Cunnane $e^{4}$ の式, 再現確率統計量 の分散の推定を jackknife 法による .

\section{（2）年最大海水位資料に対する解析}

ここでは,オランダの Hook of Holland における年最大 海水位観測資料 $\left.{ }^{5}\right)(\mathrm{n} \mathrm{cm})$ を解析に用いる 資料数は 1888 〜 1994 年の 107 年 107 個である 図 3は年最大海水位資 料の時系列を示す. 第 1 位值はオランダ南部デルタ地帯 を始め全土に大災害をもたらした 1953 年の $385 \mathrm{~cm}$, 第 2 位值は 1894 年の $327 \mathrm{~cm}$ である.また $1500 〜 1850$ 年の 351 年間に近似的に $300 \mathrm{~cm}$ の年最大海水位が 5 回 , $330 \mathrm{~cm}$ が

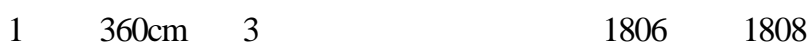
年および 1825 年) , $390 \mathrm{~cm}$ (1570 年) が 1 回の合計 10 回 記録されていることか㡾跡調査から示されている.ここ では, 標準偏差を $10 \mathrm{~cm}$ と仮定して , 300cm5 回の資料を $290,295,300,305,310 \mathrm{~cm}$ の資料 , 360cm3 回の資料を $350,360,370 \mathrm{~cm}$ の資料とみなす . 
表-1 年最大海水位資料に対する極值統計解析結果

\begin{tabular}{|c|c|c|c|c|c|}
\hline para. & $K$ & \multicolumn{2}{|c|}{$\eta_{R} \mathrm{~cm}$} & (yrs.) & \multicolumn{2}{c|}{$\sigma_{\eta_{R} \mathrm{~cm}}$} & (yrs.) \\
\cline { 3 - 7 } est. & yrs. & 1000 & 10000 & 1000 & 10000 \\
\hline MLM & 107 & 418 & 483 & 16 & 20 \\
\hline MLM & 458 & 410 & 473 & 11 & 15 \\
\hline LSM & 107 & 408 & 470 & 20 & 27 \\
\hline LSM $^{*}$ & 458 & 415 & 469 & 20 & 28 \\
\hline PPWM & 107 & 410 & 472 & 16 & 21 \\
\hline PPWM & 458 & 405 & 467 & 13 & 17 \\
\hline
\end{tabular}

opt. dist. ; Gumbel , * : Weib2 $(k=10)$

最尤法モデルによる解析では, 107 年間の観測資料 (完 全標本) に対して，計算条件を $K=107 ， K_{1}=q_{1}=0$ ， $K_{2}=107, p_{2}=q_{2}=0, K_{3}=p_{3}=q_{3}=0$ とする . 歴史資料 を考慮する場合には，閾値を ${ }_{L 3}=330 \mathrm{~cm}$ として $K=458(=351+107), K_{1}=q_{1}=0, K_{2}=107, p_{2}=0, q_{2}=0$ ， $K_{3}=351, p_{3}=346, \eta_{L 3}=330 \mathrm{~cm}, q_{3}=0$ とおく.最小 2 乗法モデルによる解析では, 107 年 107 個の観測資料 （ $K=N=107 ）$ および歴史資料を考慮する場合には $K=458$ 年で ${ }_{\mathrm{c}}=290 \mathrm{~cm}$ を越える $N=17$ 個の資料 (歴史 資料10個を含む)を対象とする 最小2乗法モデルは個々 の資料のプロッティング位置を必要とするので,上位 17 個の資料しか利用できない.さらに PPWM 法モデルに よる解析でも，107 年間の観測資料およひ歴史資料を含 む全資料を対象とする．とくに後者の場合，全資料期間 $K=458$ 年で $325 \mathrm{~cm}$ 以上 $l=7$ 個の資料, $m=107$ 年で $325 \mathrm{~cm}$ より小さい 105 個 $(325 \mathrm{~cm}$ 以上 2 個の資料を除く) の資料，下限 censoring 比 $\mu_{1}=F_{1}=0$ として，解析を 2 段 階で行う.すなわち，第 2 回目の解析では，第 1 回目の 解析で得た位置母数 $B$ を原資料から引いた資料に対し て最適分布を固定したまま計算を行ったのち，確率海水 位に上述の位置母数 $B$ を加えて, 確率海水位の最終的な 推定值とする.ここでは，より小さい標準偏差を与える 低次 PPWM $(I r s=0)$ による結果を採用する.

表-1は3つの母数推定法に基づ確率海水位と光の標 準偏差を歴史資料を考慮しない場合 ( $K=107$ 年) と考 慮する場合 ( $K=458$ 年) について交互に示す. 再現期 間 $R$ は 1,000 年と 10,000 年であり，後者は van Gelder ${ }^{5}$ に従っている．これによると，最適分布は歴史資料の考 慮の有無によらず , 1 例を除き Gumbel 分布で表わされる ことから，Gumbel 分布のみを検討対象としている van Gelder ${ }^{5}$ の候補分布の選択の妥当性か裏つけらられる.しか し，458 年の間でわずか 17 個の資料 (資料採択率 3.71\%) しか解析に含めない最小 2 乗法モデルによる結果ては ， 最適分布は形状母数 $k=10$ の尖鋭な形状をもつ Weibull 分布をとり, 相関係数も低い值にとどまっている. 全体 を通じてみると，確率海水位は再現期間 10,000 年に対し

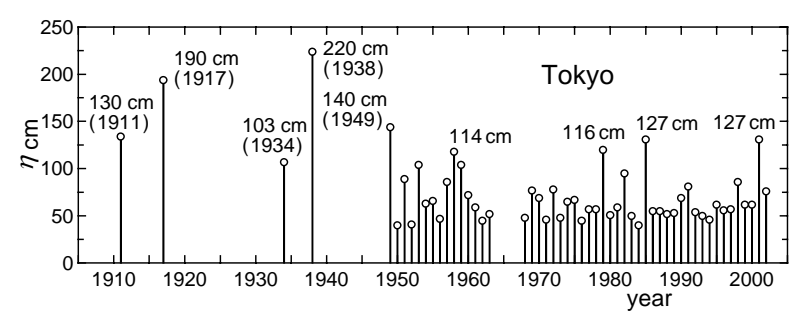

図-4 年最大高潮偏差資料の時系列

ても歴史資料の有無や母数推定法によらず光れほど有意 な差をもたないが, 確率海水位の標準偏差は歴史資料の 導入によって，とくに最尤法モデルの場合に有意な゙減少 を生じる . 因みに , 最尤法モデルに基づく 10,000 年確率 海水位と炎の標準偏差は歴史資料を考慮しない場合 483 $\pm 20 \mathrm{~cm}$ ，考慮する場合 $473 \pm 15 \mathrm{~cm}$ と評価される．

\section{（3）年最大高潮偏差資料に対する解析}

図-4は東京での 1911〜2002 年の 92 年間における年最 大高潮偏差観測資料 $(\mathrm{n} \mathrm{cm})$ の時系列を示す .1949〜2002 年の 54 年間では, 1964〜1967 年の 4 年間を除いて年最 大值資料か取得されているが, 1911〜1948 年の 38 年間 では 4 年相当分が得られるにすぎない . 解析では，1911 〜 1948 年の 38 年間のうち 34 年間の年最大值は 1934 年 の103cm を上まわらないとみなすとともに ,1964〜1967 年の 4 年相当分の值を不明とする .

最尤法モデルでは，全資料の期間 $K=92$ を歴史資料の 期間 $K_{1}=0$, 新しい時代の観測期間 $K_{2}=54$, 古い時代の 観測期間 $K_{3}=38$ に分け, 古し期間の下限 censoring 值を $\eta_{L 3}=103 \mathrm{~cm}$ と固定したうえで，新しい期間の下限 censoring 值 $L_{L 2}$ を 5 通りに変化させて計算を行う . 因み に ${ }_{L 2}=36 \mathrm{~cm}$ の場合 , $K=92, K_{1}=q_{1}=0, K_{2}=54, p_{2}=4$, $q_{2}=0, K_{3}=38, p_{3}=34, q_{3}=0$ である $\cdot \eta_{L 2}$ の増加とと もに確率高潮偏差は変化し, 弚の標準偏差も大きくなる が , 確率高潮偏差力比較的安定する ${ }_{L 2}=46 \mathrm{~cm}$ 以上の結 果のうち， $\eta_{L 2}=50 \mathrm{~cm}$ に対する結果を採用する.最小 2 乗法モデルおよび PPWM 法モデルでは， 92 年間の資料 に対して下限 censoring 值を ${ }_{L}=36 \mathrm{~cm}$ から順次変化させ た計算を行う . 確率高潮偏差は下限 censoring 值 $\eta_{L}$ にあ まり依存しないが, ,光の標隼偏差は下限 censoring 值力増 加するとともに増加し, 相関係数の值は減少することか ら，下限 censoring 值を $50 \mathrm{~cm}$ とする結果を採用する.

表-2は3 種類のモデルによる極值統計解析結果の一覧 であり，再現期間は 200 年としている . 相関係数はいず れのモデルでも 0.993 をとり，最適分布の適合度力比較 的高い．また，最適分布はいずれも Weibull 分布である が, 形状母数の值は母数推定法ごとに若干異なる. 確率 高潮偏差は最小 2 乗法モデルによる場合に , 標準偏差は 最尤法モデルによる場合にやや小さい. しかし , 兴の差 
表- 2 年最大高潮偏差資料に対する極值統計解析結果

\begin{tabular}{|c|c|c|c|c|}
\hline $\begin{array}{c}\text { para. } \\
\text { est. }\end{array}$ & $\eta_{200}(\mathrm{~cm})$ & $\sigma_{\eta_{200}(\mathrm{~cm})}$ & $\begin{array}{c}\text { opt. } \\
\text { dist. }\end{array}$ & $k$ \\
\hline MLM & 233 & 32 & Weib2 & 0.7 \\
\hline LSM & 226 & 35 & Weib2 & 0.9 \\
\hline PPWM & 239 & 34 & Weib2 & 0.8 \\
\hline
\end{tabular}

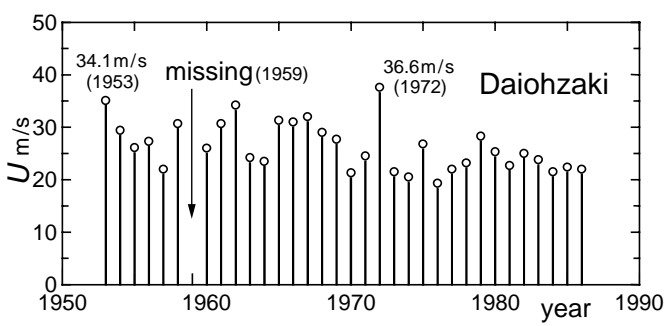

図-5 年最大風速資料の時系列

表- 3 年最大風速資料に対する極值統言十解析結果

\begin{tabular}{|c|c|c|c|c|}
\hline $\begin{array}{c}\text { para. } \\
\text { est. }\end{array}$ & $U_{100}(\mathrm{~m} / \mathrm{s})$ & $\sigma_{U 100}(\mathrm{~m} / \mathrm{s})$ & $\begin{array}{c}\text { opt. } \\
\text { dist. }\end{array}$ & $k$ \\
\hline MLM & 42.9 & 2.8 & Weib2 & 1.5 \\
\hline LSM & 42.7 & 3.6 & Weib2 & 1.4 \\
\hline PPWM & 43.9 & 2.8 & Weib2 & 1.3 \\
\hline
\end{tabular}

はあまり有意でない , 因みに , 最尤法モデルによれば， 200 年確率高潮偏差 $\eta_{200}$ と光の標準偏差 ${ }_{\eta 200}$ は $233 \pm$ $32 \mathrm{~cm}$ と評価される .

\section{（4）年最大風速資料に対する解析}

図-5は志摩半島先端の大王崎灯台て観測された1953〜 1986年の34年間にわたる年最大風速資料 $(U \mathrm{~m} / \mathrm{s})$ の時系 列を表わす.第1位風速は1959年の台風5915号 (伊勢湾台 風) 時に生起したはずであるが，欠測となっており，1972 年の 7220 号に伴う $36.6 \mathrm{~m} / \mathrm{s}$ 第1位値を占める .

最尤法モデルては，観測期間 $K_{2}$ における第 1 位値 $U_{U 2}$ か次落しているとして $, K=34, K_{1}=p_{1}=0, K_{2}=34, p_{2}=0$, $q_{2}=1, U_{U 2}=36.6, K_{3}=p_{3}=q_{3}=0$ とおく. 最小2乗法モ デルでは，第1位值を空位，第2位値を 36.6 , 以下順次， 第3位檤口第34位值として各資料の非超過確率を求める ことにより,解析を進める.PPWM法では, 上位削除数 1をもつ上限censoring問題として計算を行う .

表-3は極值統計解析結果の一覧を示す 再現期間は100 年としている.最適分布はいずれもWeibull分布をとり， 形状母数は母数推定法によって1.3〜1.5の範囲にある 最 尤法モデル (jackknife法によるbias補正) と最小2乗法モ デルによる確率風速は同程度であるが 標準偏差は最小2
乗法モデルの場合に大きい . PPWM法モデルは最尤法モ デルや最小2乗法モデルよりやや大きい確率風速を生じ るが, 標準偏差については, 最尤法モデルと同程度で最 小2乗法モデルより小さい 、因みに最尤法モデルによると， 100 年確率風速 $U_{100}$ と炎の標準偏差 $\sigma_{U 100}$ は $42.9 \pm 2.8 \mathrm{~m} / \mathrm{s}$, 変動係数は6.8\%であるから, 確率風速推定值の信頼区間 はかなり狭く, 弚の精度は高い。

\section{5. 結 語}

本論文で得られた知見の概要はつぎのようである . (1)最尤法は , 第 1 種 censored sample の場合 , 他の方法に 比べて小さい bias とVar を与えることから，不偏性と有 効性に関して優れているが. 第 2 種 censored sample の場 合 , 負の bias を生じる傾向にある . 観測青報行列法は censoring 条件によらず jackknife 法より高い精度をもつ． (2)最小 2 乗法は，第 1 種上限・上下限 censoring 条件の場 合を除いて , 分布の種類 , censoring の種類や条件によら ず有意な bias を生じないが，最尤法に比べて大きいVar を与える また jackknife法は第2 種上限・上下限censoring 条件の場合を除いて，高い精度をもつ。

(3)PPWM 法は bias , Var および jackknife 法による分散推 定值の精度からみて , 最尤法や最小 2 乗法に優る方法と は必ずしも言えない .

(4)種々の censoring を受けた年最大值観測資料に対する 極值統計解析において，最尤法モデルは最小 2 乗法モデ ルや PPWM 法モデルと同程度の再現確率統計量の推定 值を与えるが , 有効性において優れている .

参 考 文 献

1）山口正隆・畑田佳男·大福 学・前川隆海: censoring を考 慮した極值統計解析モデルおよひ現地観測資料への適用， 海岸工学論文集, 第 45 巻, pp.216-220, 1998.

2) 合田良實 : 港湾構造物の耐波設計一波浪工学への序説-， 鹿島出版会, 333p. , 1990.

3) 山口正隆 ·宇都宮好博 - 野中浩一- 真鍋 晶 - 畑田佳男 : censoring を伴う年最大值資料に対する極值統計解析にお ける PWM 法の適用性, 海岸工学論文集, 第 51 巻, pp.186-190, 2004.

4) 宝 馨: 現代水文統計論-水文頻度解析のモデル,手法と光 の評価, 1998 年度 (第 34 回) 水工学に関する夏期研修会 講義集，A コース，A-8-1-20，1998.

5) van Gelder, P.H.A.J.M : Statistical Methods for the Risk-Based Design of Civil Structures, PhD thesis, Delft Univ. of Tech., pp.173-187, 2000.

(2005. 9. 30受付) 